Article

\title{
Construction and Degradation Performance Study of Polycyclic Aromatic Hydrocarbons (PAHs) Degrading Bacterium Consortium
}

\author{
Long Zhang ${ }^{1}$, Bo Yang ${ }^{1, *}$, Chengtun $Q u^{1,2}$, Gang Chen ${ }^{1}$, Feng $Q i^{3}{ }^{\circledR}$, Tao $\mathrm{Yu}^{1}$ and Azlin Mustapha ${ }^{4}$ \\ 1 Shaanxi Oil and Gas Pollution Control and Reservoir Protection Key Laboratory, College of Chemistry and \\ Chemical Engineering, Xi'an Shiyou University, Xi'an 710065, China; zhanglong1149@163.com (L.Z.); \\ xianquct@163.com (C.Q.); gangchen@xsyu.edu.cn (G.C.); $180708 @ x s y u . e d u . c n$ (T.Y.) \\ 2 State Key Laboratory of Petroleum Pollution Control, CNPC Research Institute of Safety and Environmental \\ Technology, Beijing 102206, China \\ 3 Department of Mechanical and Aerospace Engineering, University of Missouri-Columbia, \\ Columbia, MO 65211, USA; gielcheen@gmail.com \\ 4 Food Science Program, University of Missouri-Columbia, Columbia, MO 65211, USA; \\ mustaphaa@missouri.edu \\ * Correspondence: yangbo@xsyu.edu.cn
}

Citation: Zhang, L.; Yang, B.; Qu, C.; Chen, G.; Qi, F.; Yu, T.; Mustapha, A. Construction and Degradation Performance Study of Polycyclic Aromatic Hydrocarbons (PAHs) Degrading Bacterium Consortium. Appl. Sci. 2022, 12, 2354. https:// doi.org/10.3390/app12052354

Academic Editor: Maris Klavins

Received: 29 December 2021

Accepted: 21 February 2022

Published: 24 February 2022

Publisher's Note: MDPI stays neutral with regard to jurisdictional claims in published maps and institutional affiliations.

Copyright: (c) 2022 by the authors. Licensee MDPI, Basel, Switzerland. This article is an open access article distributed under the terms and conditions of the Creative Commons Attribution (CC BY) license (https:// creativecommons.org/licenses/by/ $4.0 /)$.

\begin{abstract}
PAHs are widely distributed in the environment and pose a serious threat to ecological security and human health. The P\&A (Pseudomonas aeruginosa and Alcaligenes faecalis) bacterium consortium obtained in this study comes from oily sludge and is reused for the degradation of PAHs mixture in oily sludge. Few articles pay attention to the PAHs mixture in oily sludge and reuse the bacterium consortium for its degradation. The PAHs solution degradation efficient of P\&A bacterial consortium under different environmental conditions, bioaugmentations, and exogenous stimulations were studied by ultraviolet visible spectrophotometer and gas chromatography-mass spectrometry. The result shows that, after 8 days of degradation under $35^{\circ} \mathrm{C}$, $\mathrm{pH} 7$, with $5 \%$ (volume percent) of the inoculation amount, the degradation rate of NAP, PHE, and PYR solution could higher than $90 \%, 80 \%$, and $70 \%$, respectively. The additional crude oil could further improve the NAP, PHE, and PYR degradation efficiency. The minimum inhibitory concentration of $\mathrm{Cu}^{2+}, \mathrm{Zn}^{2+}$, and $\mathrm{Pb}^{2+}$ to bacterium were 2.002, 17.388, and $9.435 \mathrm{mM}$, respectively. The addition of surfactants had negative or limited positive effect on the PAHs degradation rate. Furthermore, the average degradation rates of NAP, PHE, and PYR, in oily sludge of local petroleum polluted area by P\&A bacterial consortium, could all reach above $80 \%$. Based on gas chromatography-mass spectrometry test results before and after incubation, P\&A bacterial consortium also provides more opportunities for other organic compounds' degradation.
\end{abstract}

Keywords: PAHs degradation; bacterial consortium; P. aeruginosa and A. faecalis; oily sludge

\section{Introduction}

PAHs, which are formed by direct connection, bending connection, or aggregation of multiple benzene rings [1-3], mainly occur during incomplete combustion [4] of fossil fuel, such as coal, oil, and gas, waste incineration sites, or the formation of crude oil [5,6], and are a class of compounds with genotoxicity, carcinogenicity, mutagenicity, and teratogenicity $[7,8]$. Studies have shown that PAHs and their derivatives could pose a threat to almost all organisms. PAHs have long-term health effects even at low levels, such as cataracts, kidney and liver damage, and jaundice, because they are persistent in the environment. They are highly lipophilic and readily adsorb onto particles in both water and aerosols, indicating that exposure to PAHs can occur through inhalation of atmospheric particles, ingestion of contaminated particles (e.g., soil), or dermal contact with contaminated material (e.g., soil, sediment, and water) [9-15]. In the early 1980s, the United States Environmental Protection 
Agency (EPA) listed 16 PAHs as environmental priority monitoring pollutants $[16,17]$. The European Commission and China also identified PAHs as priority hazardous substances causing environmental and human health concerns [18].

Because of rigid aromatic structure, high partition coefficient, and high resonance energy, this type of persistent organic compounds easily absorbs on organic substances above the soil or sediment particle. Moreover, PAHs exist in crude oil and incomplete combustion products of oil, so oil sludge contains a large number of PAHs. The low fluidity, high emulsification, and complex components (e.g., residual oils, benzene series, aromatic hydrocarbons, polychlorinated biphenyls, asphaltenes, colloids, bacteria, and toxic heavy metal elements) of oil sludge also increase the difficulty of PAHs degradation. Therefore, PAHs in oily sludge has become one of the difficulties and hotspots of its harmless.

Although PAHs in oily sludge can be degraded or eliminated by volatilization, ultraviolet photolysis, or chemical oxidation $[19,20]$, biodegradation technology $[21,22]$ has the incomparable superiority compared to the traditional method with cost-effectiveness and non-invasion advantages. Natural terrestrial plants in nature, tall fescue, willow, reed, and sudangrass [23-27] can promote the decomposition of PAHs through the rhizo-degradation effect. In addition, various forms of bacterium that can survive in oily sludge (Pseudomonas, Bacillus, and Acinetobacter) and fungus (White rot fungi) [28-31] can be isolated and cultured and then reused for the degradation of PAHs in oily sludge, which can not only quickly adapt to the complex degradation environment but also contribute important roles in the aspect of PAHs' biodegradation.

Furthermore, many studies have noticed that the bacterial consortium promoted better organics degradation effects from individual bacteria [32]. The possible reason is that, in the process of bacterial consortium degradation, since the intermediate biotransformation product of one bacteria can be used as the basis for the catabolism and growth of others, a better degradation efficiency of mixed PAHs could be achieved by bacterial consortium [33]. Based on strong synergistic metabolism, the response to complex environment, and degradability to multiple pollutants [34] advantages, bacterial consortium technology has become the first option for PAHs and heterocyclic derivatives degradation method in recent years.

The research focused on the PAHs mixture of oily sludge, the bacteria in oily sludge were used to construct the bacterial consortium and reused for the degradation of PAHs mixture in oily sludge. In this study, 10 bacteria isolated from oily sludge were used to catabolize bicyclic NAP (naphthalene), tricyclic PHE (phenanthrene) and tetracyclic PYR (pyrene). The single variable method was used to screen and construct, optimized and improve the P\&A bacterial consortium activity. During the experiment, UV-vis (ultraviolet visible) spectrophotometer and GC-MS (gas chromatography-mass spectrometry) were used to detect the residual amount of NAP, PHE, and PYR in solution. Moreover, GC-MS and qualitative analysis software were also used to identify the types of organic compounds in oily sludge. The P\&A bacterial consortium obtained in this study can not only effectively degrade NAP, PHE, and PYR but also degrade Acenaphthylene, 1H-Phenalene, $4 \mathrm{H}-\mathrm{Cyclopenta}[\mathrm{d}, \mathrm{e}, \mathrm{f}]$ phenanthrene, Fluoranthene, Triphenylene, 9H-Cyclopenta[a]pyrene, and Benzo[k]fluoranthene. This work could greatly increase the application range of bacterial consortium and is promising in the degradation of PAHs contents' oily sludge in a petroleum-polluted area.

\section{Experimental Methods and Materials}

\subsection{Materials}

The NAP (naphthalene, analytical pure), PHE (phenanthrene $97 \mathrm{wt} \%$ ), and PYR (pyrene $97 \mathrm{wt} \%$ ) were purchased from local store. The crude oil (70.26\% saturated hydrocarbon, $12.54 \%$ aromatic hydrocarbon, $7.38 \%$ asphaltene, and $9.82 \%$ gum) and oil sludge (oil content 5.62\%, $0.2090 \mathrm{mg} / \mathrm{g}$ NAP, $3.1116 \mathrm{mg} / \mathrm{g}$ PHE, $1.00595 \mathrm{mg} / \mathrm{g}$ PYR, and organic compounds are mainly aromatic hydrocarbons) were collected from a local oil-polluted area in Shaanxi Province, China. 
GC-MS (7890B-5977B, Agilent Technologies Inc., Palo Alto, CA, USA), autoclave (LDZX-30KBS, Shanghai Shen'an Medical Instrument Factory, Shanghai, China), vortex turbidimeter (Vortex-2, Shanghai Hushi Industrial Co., Ltd., Shanghai, China), ultrasonic cleaner (KQ-100DE, Kunshan Ultrasonic Instrument Co., Ltd., Kunshan, China), bed temperature incubator (GTCS-2011, Changzhou Zhengrong Instrument Co., Ltd., Changzhou, China), biochemical incubator (SPX-250BIII, Tianjin taist Instrument Co., Ltd., Tianjin, China), UV-vis spectrophotometer (T2600, Shanghai Youke Instrument Co., Ltd., Shanghai, China), low-speed bench centrifuge (TDL-80-2B, Shanghai Anting Scientific Instrument Co., Ltd., Shanghai, China), etc.

\subsection{Experimental Procedures}

\subsubsection{Basic Bacterium Information Test}

The basic bacterium of oil sludge was tested by the streak plate method. After the individual bacteria were inoculated on Luria-Bertani (LB) liquid medium and incubated for $12 \mathrm{~h}$ at $35^{\circ} \mathrm{C}$, then transferred to LB solid medium and cultivation in biochemical incubator for $24 \mathrm{~h}$ at $35^{\circ} \mathrm{C}$, the color, transparency, cell shape, and cell morphology were observed and recorded. The bacteria were stored in a refrigerator at $4{ }^{\circ} \mathrm{C}$. The basic information of 10 bacteria was tested in this study, the result is shown in Table 1.

Table 1. Basic information of bacteria.

\begin{tabular}{|c|c|c|c|c|c|c|}
\hline \multirow{2}{*}{ NO. } & \multirow{2}{*}{ Name } & \multicolumn{5}{|c|}{ Characteristics of Colony } \\
\hline & & Colour & Transparency & Edge & Cell Morphology & GenBank Number \\
\hline $1-1$ & Pseudomonas aeruginosa A & White & Opaque & Neat & Bacilli & KX665604 \\
\hline $1-2$ & Microbacterium oxidans & Light yellow & Translucent & Neat & Bacilli & KX665599 \\
\hline $1-3$ & $\begin{array}{l}\text { Ochrobactrum } \\
\text { intermedium }\end{array}$ & Milky white & Opaque & Neat & Bacilli & KX665600 \\
\hline $1-4$ & Stenotrop Homonas & Milky white & Opaque & Neat & Bacilli & KX665603 \\
\hline $1-5$ & Brevibacillus laterosporus & Grayish white & Opaque & Untidy & Bacilli & KX665602 \\
\hline $1-6$ & Alcaligenes faecalis & White & Transparent & Untidy & Corynebacterium & KX665601 \\
\hline $2-1$ & Pseudomonas aeruginosa B & Grayish green & Translucent & Neat & Bacilli brevis & - \\
\hline $2-2$ & Achromobacter sp. & Yellow & Translucent & Neat & Bacilli brevis & - \\
\hline $2-3$ & Cellulomonas & Light yellow & Opaque & Untidy & Bacilli & - \\
\hline $2-4$ & Serratia marcescens & Dark red & Opaque & Untidy & Bacilli brevis & - \\
\hline
\end{tabular}

\subsubsection{GC-MS Operating Conditions}

Chromatographic column: DB-5MS (30 $\mathrm{m} \times 0.25 \mathrm{~mm} \times 0.25 \mathrm{um}$ ), split ratio: 10:1, Temperature: $280{ }^{\circ} \mathrm{C}$, Injection Volume: $1.0 \mathrm{uL}$, Column Flow: $1.0 \mathrm{~mL} / \mathrm{min}$ (constant flow), Column Temperature: $80{ }^{\circ} \mathrm{C}$ for $2 \mathrm{~min}$, Rise to $180{ }^{\circ} \mathrm{C}\left(20^{\circ} \mathrm{C} / \mathrm{min}\right)$ keep for $5 \mathrm{~min}$, Rise to $290^{\circ} \mathrm{C}\left(10^{\circ} \mathrm{C} / \mathrm{min}\right)$ keep for $5 \mathrm{~min}$, Electron Bombardment Source: EI, Ion source Temperature: $230^{\circ} \mathrm{C}$, Ionization Energy: $70 \mathrm{ev}$, Interface Temperature: $280^{\circ} \mathrm{C}$, Quadrupole Temperature: $150{ }^{\circ} \mathrm{C}$, Mass Scanning Range: $45-450 \mathrm{u}$, Solvent delay Time: $5 \mathrm{~min}$, Scanning Mode: full scan scan/SIM (Ion Mode).

\subsubsection{Quantitative Analysis of Single and Mixture PAHs}

Cyclohexane (q.s) was added into the medium and shaken on the vortex turbidimeter for $5 \mathrm{~min}$, followed by centrifuging for $10 \mathrm{~min}$ at $3000 \mathrm{rpm}$, and the organic phase was collected. Cyclohexane (q.s) was added again to the aqueous phase, repeat shaken, centrifuged, and collected three times. The extract was extracted to a sand core funnel containing $5 \mathrm{~mm}$ of anhydrous $\mathrm{Na}_{2} \mathrm{SO}_{4}$ to absorb water for $1 \mathrm{~h}$. The organic phase was collected, and the absorbance was determined by the UV-vis spectrophotometer $[35,36]$. 
The residuals of single NAP, PHE, and PYR in the medium were calculated according to the standard curve.

Hexyl hydride (q.s) was added into the medium and shaken on the vortex turbidimeter for $5 \mathrm{~min}$, followed by ultrasonic extraction below $35^{\circ} \mathrm{C}$ for $30 \mathrm{~min}$ and centrifugation at $3000 \mathrm{rpm}$ for $10 \mathrm{~min}$, and the organic phase was collected. The organic phase was extracted to a sand core funnel containing $5 \mathrm{~mm}$ anhydrous $\mathrm{Na}_{2} \mathrm{SO}_{4}$ to absorb water for $1 \mathrm{~h}$. Then, a $10 \mathrm{~mL}$ glass syringe was used to inject the dehydrated organic phase through a $0.22 \mu \mathrm{m}$ membrane into the sample vial. The residual of NAP, PHE, and PYR in the medium were determined by GC-MS. The residual of mixed PAHs in the sample was calculated according to the standard curve.

\subsubsection{Quantitative Analysis of Crude Oil}

The medium was transferred into a $250 \mathrm{~mL}$ separating funnel, and petroleum ether and 1:1 $\mathrm{H}_{2} \mathrm{SO}_{4}$ were added into separating funnel to completely integrate the crude oil into the organic phase. After standing for $30 \mathrm{~min}$, the aqueous phase was released from below and the organic phase was poured out from above. The absorbance was determined by UV-vis spectrophotometer, and the residual of crude oil in the medium was calculated according to the standard curve $[35,36]$.

\subsubsection{Sensitivity Analysis of P\&A Bacterial Consortium to Heavy Metal Ions}

The circular filter papers with a diameter of $6 \mathrm{~mm}$ were submerged into $\mathrm{CuSO}_{4} \cdot 5 \mathrm{H}_{2} \mathrm{O}$, $\left(\mathrm{Pb}\left(\mathrm{NO}_{3}\right)_{2}\right.$, and $\left.\mathrm{ZnSO}_{4} \cdot 7 \mathrm{H}_{2} \mathrm{O}\right)$ standard solution with concentrations of $0.1,0.5,1,5,10$, and $20 \mathrm{~g} / \mathrm{L}$, respectively. After let the papers dried overnight at $37^{\circ} \mathrm{C}$ and autoclaved, the drug sensitivity test paper (DSTP) was made. A total of $0.25 \mathrm{~mL}$ of bacterial solution with optical density $600=1.0\left(\mathrm{OD}_{600}=1.0\right)$ was applied evenly on LB solid medium, and six pieces of DSTP were lied tightly on it, then cultured at $35^{\circ} \mathrm{C}$ for $24 \mathrm{~h}$. The size of the bacteriostatic circle around the paper were recorded to detect whether there is bacteriostatic effect.

\subsubsection{Resistance Analysis of P\&A Bacterial Consortium to Heavy Metal Ions}

Stepwise dilution method was used for MIC (minimum inhibitory concentration) test by using 11 tubes with number $0-10$, then $250 \mathrm{mg} \mathrm{CuSO} \cdot 5 \mathrm{H}_{2} \mathrm{O}, \mathrm{Pb}\left(\mathrm{NO}_{3}\right)_{2}$ and $\mathrm{ZnSO}_{4} \cdot 7 \mathrm{H}_{2} \mathrm{O}$ were diluted into $5 \mathrm{~mL}$ LB liquid medium in tube No. 0, $2.5 \mathrm{~mL}$ LB liquid medium was added into tubes No. 1-10, and after that, $2.5 \mathrm{~mL}$ of solution from tube No. 0 were injected into tube No. 1 , and the rest of the tubes from 2-8 could be performed in the same manner, respectively. Then, $0.25 \mathrm{~mL}$ of bacterial solution with $\mathrm{OD}_{600}=1.0$ was injected into autoclaved tubes No. $0-9$. All test tubes were cultured in a biochemical incubator at $35^{\circ} \mathrm{C}$ for 3 days. The heavy metal ion concentration of the tube without visible bacterial growth is the MIC of the bacterium.

\subsubsection{PAHs Degradation Experiment}

The individual bacteria on the LB solid medium was inoculated with an inoculation ring into LB liquid medium and cultured for $24 \mathrm{~h}$ at $35^{\circ} \mathrm{C}$. Then, $5 \mathrm{~mL}$ of bacterial solution was transfered into new LB liquid medium and cultured until $\mathrm{OD}_{600}=1.0$. Inoculate a total of $5 \mathrm{~mL}$ of a bacterial solution with $\mathrm{OD}_{600}=1.0$, whose viable bacteria count result is $10^{10} \mathrm{CFU} / \mathrm{mL}$, into a PAHs (NAP, PHE and PYR) contained medium. The residual NAP, PHE, PYR, and crude oil in the PAHs degradation medium were calculated according to the methods in Sections 2.2.2 and 2.2.3 after 8 days of degradation in different conditions. Flow charts of heavy metal ions and PAHs degradation experiment are shown in Figure 1. 


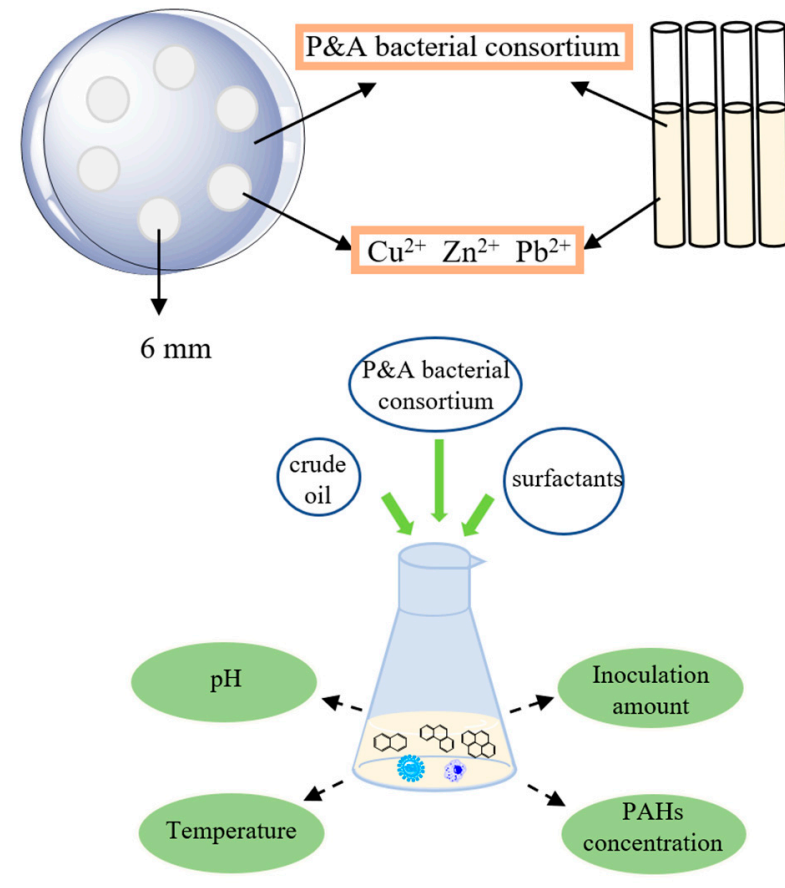

Figure 1. Flow chart of heavy metal ions and PAHs degradation experiment.

\section{Results and Discussion}

\subsection{Construction of PEA Bacterial Consortium}

3.1.1. Optimization of PAHs Degradation by Individual Bacteria Optimization of Individual Bacteria by Single PAHs

Each of 10 bacteria was used to consume $500 \mathrm{mg} / \mathrm{L} \mathrm{NAP,} 50 \mathrm{mg} / \mathrm{L}$ PHE, and $100 \mathrm{mg} / \mathrm{L}$ PYR, respectively $[37,38]$, and the absorbances of the solutions were determined by UV-vis spectrophotometer on Days 2, 4, 6, 8, and 10. Within 10 days of consumption, the average degradation rates of NAP, PHE, and PYR were continuing to increase up to $90.24 \%, 34.17 \%$, and $34.36 \%$, respectively (Figure 2), but the increase rates on Days 8-10 were significantly slower than others, so the degradation time of subsequent experiments was determined to be 8 days.

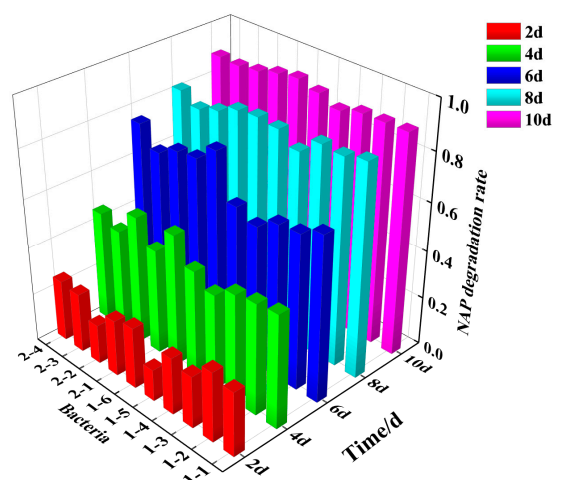

(a) NAP

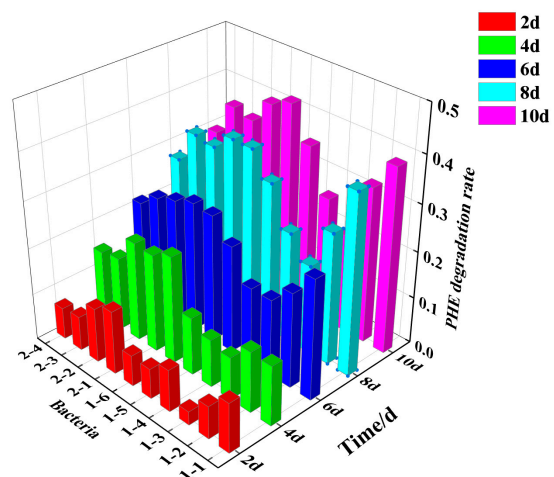

(b) PHE

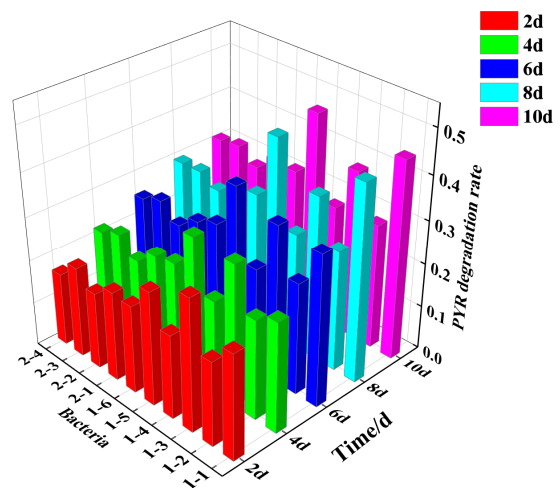

(c) PYR

Figure 2. Degradation rates of single PAHs by purebred strain.

It could be also seen that the degradation rates of NAP by 10 strains were all about $80 \%$ (Figure $2 \mathrm{a}$ ) within 8 days. The top six bacterium with the best degradation effect on NAP, PHE, and PYR and their degradation rates within 8 days are shown in Table 2. 
Table 2. The best degradation rates of NAP, PHE, and PYR within 8 days.

\begin{tabular}{ccccccc}
\hline & \multicolumn{2}{c}{ NAP } & \multicolumn{2}{c}{ PHE } & \multicolumn{2}{c}{ PYR } \\
\cline { 2 - 7 } Serial NO. & NO. & $\begin{array}{c}\text { Degradation } \\
\text { Rates }\end{array}$ & NO. & $\begin{array}{c}\text { Degradation } \\
\text { Rates }\end{array}$ & NO. & $\begin{array}{c}\text { Degradation } \\
\text { Rates }\end{array}$ \\
\hline 1 & $1-1$ & $87.40 \%$ & $1-1$ & $38.58 \%$ & $1-5$ & $45.83 \%$ \\
2 & $1-3$ & $86.05 \%$ & $2-1$ & $37.15 \%$ & $1-1$ & $44.88 \%$ \\
3 & $1-2$ & $85.36 \%$ & $1-6$ & $37.10 \%$ & $1-3$ & $37.42 \%$ \\
4 & $1-6$ & $85.25 \%$ & $2-3$ & $34.35 \%$ & $1-6$ & $31.02 \%$ \\
5 & $1-5$ & $84.36 \%$ & $2-2$ & $33.69 \%$ & $2-1$ & $30.29 \%$ \\
6 & $2-1$ & $84.28 \%$ & $1-5$ & $31.99 \%$ & $2-3$ & $29.73 \%$ \\
\hline
\end{tabular}

Figure 2 and Table 2 show that, NAP, PHE, and PYR degradation rates reach $87.40 \%$, $38.58 \%$, and $44.88 \%$ when $1-1$ was used, and $84.28 \%, 37.15 \%$, and $30.29 \%$ when $2-1$ was used. Bacteria 1-1 and 2-1 belong to Pseudomonas, with the most extensive degradation object range and species so far [39]. One strain of P. anguiliseptica isolated from an urban area was reported with both degradtion of PAHs and improved degradation efficiency of bacterial consortium [40].

Similarly, based on the results in Figure 2 and Table 2, NAP, PHE, and PYR degradation rates reach $84.36 \%, 31.99 \%$, and $45.83 \%$ when $1-5$ was used, and $85.25 \%, 37.10 \%$, and $31.02 \%$ when 1-6 was used. Bacteria 1-5 and 1-6 belong to Bacillus and Alcaligenes, respectively. Four potential candidates with higher degradation effect single substance of PAHs were selected from 10 bacteria.

Optimization of Individual Bacteria by Mixed PAHs

Since PAHs persistently exist in mixture forms in the natural [41], the bacterium comprehensive degradation capacity for all NAP, PHE, and PYR compounds should be considered. Four optimum individual bacterium (1-1, 2-1, 1-6, and 1-5) were used as degradation bacteria. The mixed $200 \mathrm{mg} / \mathrm{L} \mathrm{NAP,} 20 \mathrm{mg} / \mathrm{L}$ PHE, and $40 \mathrm{mg} / \mathrm{L}$ PYR were used to test the degradation capacity for bacterium, that selected above, to find the optimum mixed PAHs degradation bacterium.

NAP degradation rates was not used, since all bacteria could degrade the $200 \mathrm{mg} / \mathrm{L}$ NAP completely (Figure 3). In the mixed PAHs system, the degradation rates shown in Figure 3 for PHE and PYR were $79.24 \%$ and $65.09 \%$, and $89.11 \%$ and $79.14 \%$, when the Bacteria 1-1 and 1-6, were used respectively. Bacteria 1-1 and 1-6 showed better degradation effects than 1-5 and 2-1. Since Bacteria 1-1 and 1-6 were isolated from the same oily sludge (3.1), the symbiotic relationship between 1-1 and 1-6 is possible. Based on the experiment above and basic bacterium information test results, the bacteria 1-1 and 1-6 were selected to conducting the degradation bacterium in the following studies.

\subsubsection{Optimization of Proportion of Two Individual Bacterium in Bacterial Consortium}

It is impossible that there are only individual bacteria in the natural degradation process of the pollution system. PAHs are often degraded by the bacterial consortium since the diversity of bacterial consortium is conducive to the degradation of PAHs. Some bacteria can provide oxygenase, other degradation enzymes, and growth factors to promote the degradation of PAHs through synergistic effect. For example, P. putida cannot degrade PYR without the present of Flavobacterium and its growth matrix PHE [42].

In order to optimize the bacterial proportion (volume percent) in degradation bacterial consortium, two degradation bacteria(1-1 and 1-6) were mixed in different ratios to degrad the mixture of PAHs. Since $200 \mathrm{mg} / \mathrm{L}$ NAP was completely degraded by bacteria in experiment section of Optimization of Individual Bacteria by Mixed PAHs, the NAP was increased to $500 \mathrm{mg} / \mathrm{L}$ in PAHs mixture in the following test, and the results were shown in Figure 4. 


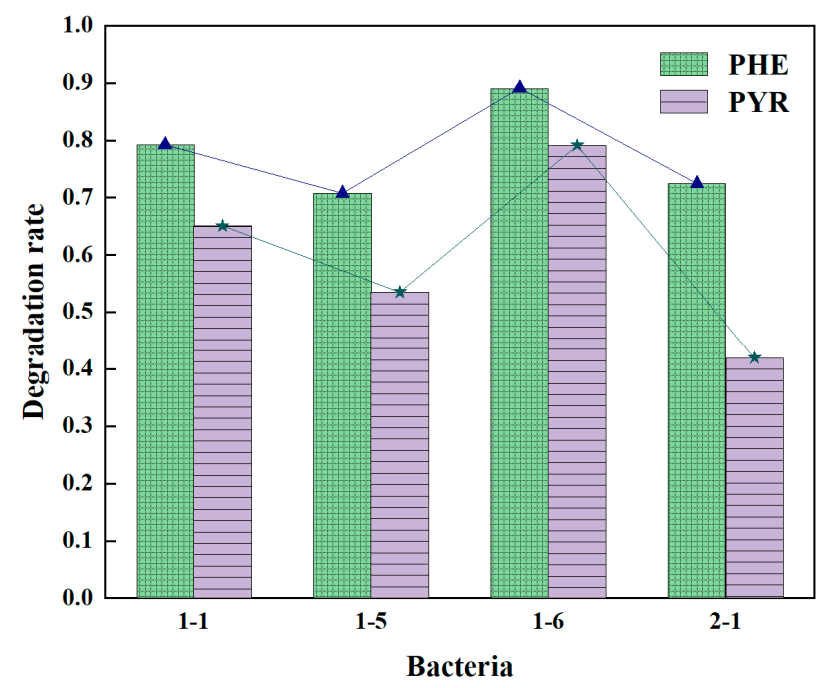

Figure 3. Degradation rates of mixed PAHs by purebred strain ( $\Delta$ : PHE degradation rate; $九$ : PYR degradation rate).

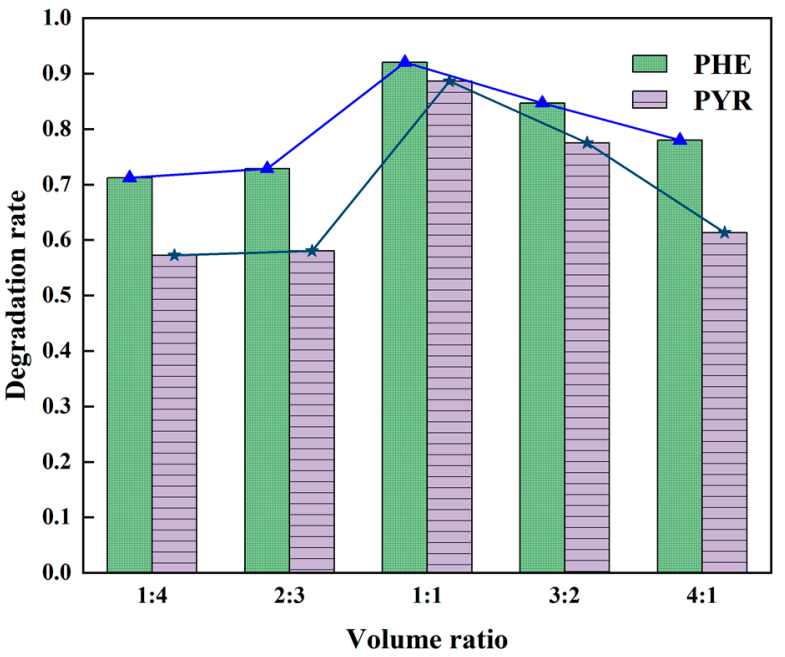

Figure 4. Degradation rates of mixed PAHs by bacteria consortium with different ratio ( $\triangle$ : PHE degradation rate; 沦: PYR degradation rate).

NAP degradation rates were not used, since all bacterial consortium could degrade the $500 \mathrm{mg} / \mathrm{L}$ NAP completely (Figure 4). It could be observed that, when the inoculation volume ratio was 1:1, the degradation rates of PHE and PYR were higher than others $(92.02 \%$ and $88.65 \%$ ) (Figure 4), which was also higher than individual bacteria 1-6 (PHE 89.11\% and PYR 79.14\%) and 1-3 (PHE 79.24\% and PYR 65.09\%) (Figure 3). This also proved the previous conjecture that there was no competitive relationship between 1-1 and 1-6, and they are interactive with each other. The synergistic effect of the two bacterium can promote the degradation rates of PHE and PYR.

Through the experiment in this section, a P\&A bacterial consortium composed of P. aeruginosa (1-1) and A. faecalis (1-6) was successfully constructed. The optimal degradation P\&A bacterial consortium was in a volume ratio of $1: 1$ when $\mathrm{OD}_{600}=1.0$ and the best degradation term under laboratory conditions was 8 days. The two bacteria were from oily sludge, which also shows the environmental adaptability of P\&A bacterial consortium.

\subsection{Effect Analysis of Environmental Factors on Degradation}

Although the P\&A bacterial consortium had been constructed, the degradation rates of NAP, PHE, and PYR also depend on environmental factors, bacteria, and PAHs 'initial 
concentrations. The effects of temperature, $\mathrm{pH}$, bacteria, and PAHs' initial concentrations on the degradation of PAHs were studied by single variable method. Since $500 \mathrm{mg} / \mathrm{L}$ NAP was completely degraded by bacterium in experiment 3.2.2, the PAHs mixture contained $2000 \mathrm{mg} / \mathrm{L}$ NAP, $20 \mathrm{mg} / \mathrm{L}$ PHE, and $40 \mathrm{mg} / \mathrm{L}$ PYR in the following test, except Experiment (c). The PAHs initial concentrations in Figure $5 \mathrm{c}$ are shown in Table 3 as follows. The results are shown in Figure 5.
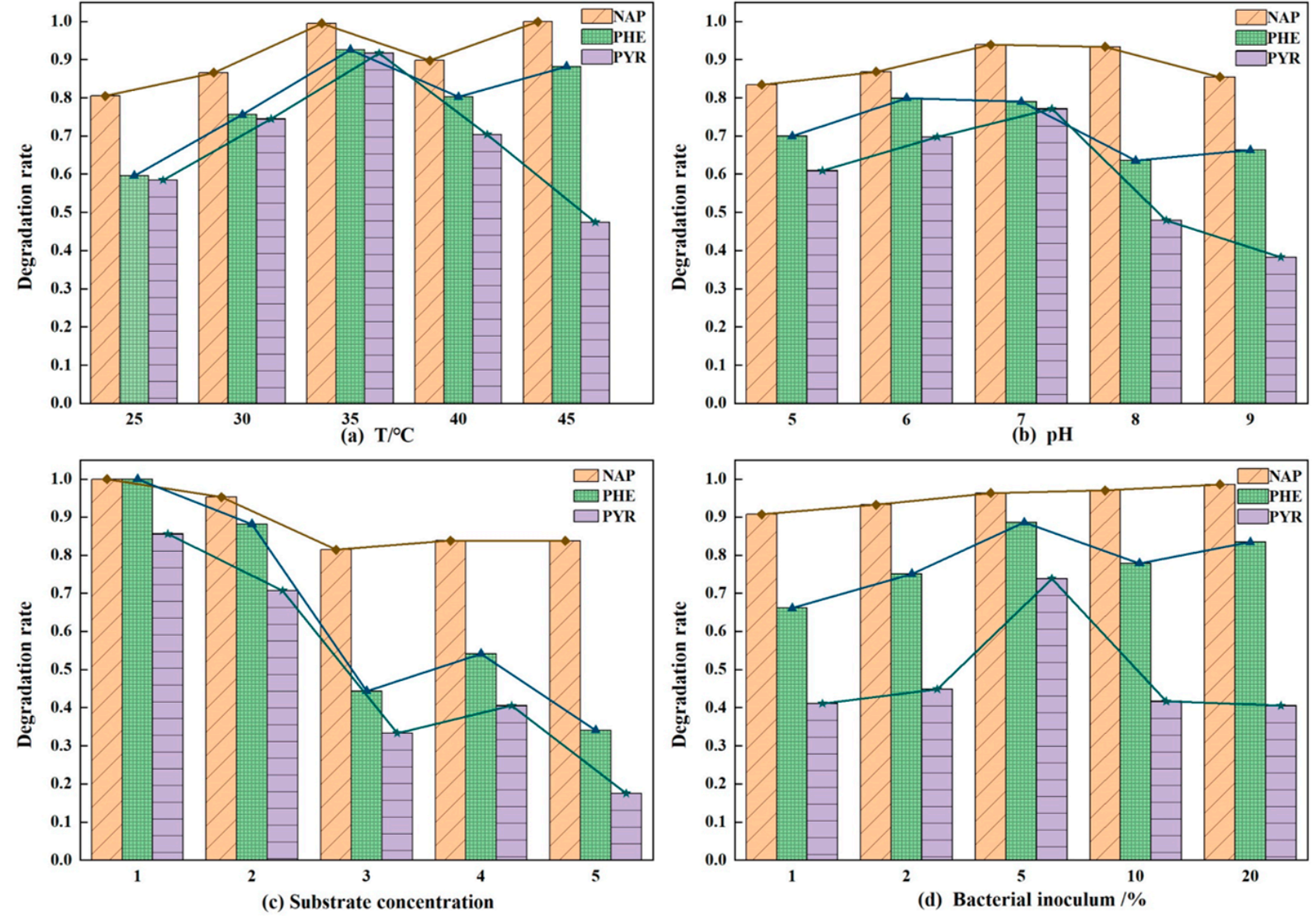

Figure 5. Effects of environmental conditions on the degradation rate of PAHs $(\diamond$ : NAP degradation rate; $\Delta$ : PHE degradation rate; 攻: PYR degradation rate).

Table 3. The PAHs initial concentrations in Figure 5c.

\begin{tabular}{cccccc}
\hline NO. & $\mathbf{1}$ & $\mathbf{2}$ & $\mathbf{3}$ & $\mathbf{4}$ & $\mathbf{5}$ \\
\hline $\mathrm{NAP} / \mathrm{mg} / \mathrm{L}$ & 1000 & 2000 & 3000 & 4000 & 5000 \\
$\mathrm{PHE} / \mathrm{mg} / \mathrm{L}$ & 10 & 20 & 30 & 40 & 50 \\
$\mathrm{PYR} / \mathrm{mg} / \mathrm{L}$ & 20 & 40 & 60 & 80 & 100 \\
\hline
\end{tabular}

The effects of environmental conditions on NAP, PHE, and PYR degradation efficiency are shown in Figure 5. It can be seen from Figure 5a that temperature is one of the most important environmental factors that is affecting the growth and survival of microorganisms; when the degradation temperature is $35^{\circ} \mathrm{C}$, the comprehensive degradation rates of NAP, PHE, and PYR are higher than others (99.51\%, 92.60\%, and 91.71\%), and when it is higher or lower than $35^{\circ} \mathrm{C}$, a considered decrease of degradation rate could be observed. Within the appropriate temperature range, the enzymatic reaction efficiency, the solubility and mass transfer rates of PAHs are increased [43,44]. Based on the Figure 5b, the higher degradation rates of NAP, PHE, and PYR could be achieved $(93.86 \%, 78.98 \%$, and $77.08 \%)$ when $\mathrm{pH}$ is 
about 7. However, the NAP, PHE, and PYR degradation rates would be decreased at other $\mathrm{pH}$, proving that the enzyme activity will be reduced if $\mathrm{pH}$ is out of the optimum $\mathrm{pH}$ range of $6.5 \sim 7.5$ [45].

With the increasing initial concentration (IC) of NAP, PHE, and PYR in the degradation system, the degradation rates showed a downward trend (Figure 5c). However, when the IC values of NAP, PHE, and PYR were 1000, 10, and $20 \mathrm{mg} / \mathrm{L}$ (Table 3), respectively, NAP and PHE were degraded by the P\&A bacterial consortium completely, and the degradation rate of PYR was as high as $85.55 \%$. In order to carry out the follow-up experiment and observe the experimental phenomenon, the dosages of NAP, PHE, and PYR in the followup experiment were determined as 2000,20, and $40 \mathrm{mg} / \mathrm{L}$, and the degradation rates of NAP, PHE, and PYR under this IC were $95.23 \%, 88.13 \%$, and $70.72 \%$, respectiveiy. The lower initial concentration of PAHs made it not only difficult to provide sufficient carbon source but also difficult to induce microorganisms to produce corresponding degrading enzymes. High-concentration PAHs have toxicity to microorganisms [29], and suitable initial concentration also is the important consideration factor for further analysis.

It can be observed from Figure $5 d$ that when the bacterial inoculum is $5 \%$ (volume percent), the degradation rates of NAP, PHE, and PYR were 96.37\%, 88.54\%, and 73.82\%, respectively, which were higher than others. The accumulation of biomass would take a long time when the bacterial inoculum is lower than the appropriate amount, but higher bacterial inoculation will lead to a large number of cell deaths because of nutrient deficiency.

All above, the optimum comprehensive degradation factors about temperature are $35^{\circ} \mathrm{C}$, the $\mathrm{pH}$ is about 7, the $\mathrm{NAP}_{\mathrm{IC}}, \mathrm{PHE}_{\mathrm{IC}}$, and PYR IC are 2000, 20, and $40 \mathrm{mg} / \mathrm{L}$, respectively, and for bacterial inoculum, which with $\mathrm{OD}_{600}=1.0$ is $5 \mathrm{~mL}$ (volume percent: $5 \%$ ), the best degradation rates for NAP, PHE, and PYR are higher than $90 \%, 80 \%$, and $70 \%$, respectively. Therefore, the subsequent experiments will be carried out on this basis.

\subsection{Effect Analysis of Exogenous Substances on PAHs Degradation}

\subsubsection{Crude Oil}

During the microbial degradation of PAHs in oily sludge, the content of residual oil in sludge would affect the degradation efficiency of PAHs. Additionally, the residual oil in randomly stacked oily sludge can enter the soil directly or indirectly, affecting the physical and chemical properties and functions of the soil. Toxic substances can inactivate plant enzymes and penetrate plant structure, resulting in the failure of plant growth [46]. Furthermore, excessive residual oil would pollute groundwater after being washed by rain. After horizontal expansion in groundwater, some residual oil can enter surface runoff with runoff sediment, resulting in excessive chemical oxygen demand (COD) and petroleum substances in surface water [47]. The test of crude oil effection was conducted (Figure 6), and its effect on the degradation of NAP, PHE, and PYR by P\&A bacterial consortium was explored.

It is shown that the crude oil content factor did not impact NAP, PHE, and PYR degradation in this experiment, and all of them were completely degraded (Figure 6). Moreover, within the P\&A bacterial consortium system, the degradation rate of crude oil reached $80.85 \%$ when the addition of crude oil was $5 \mathrm{~g} / \mathrm{L}$. Compared with Section 3.2, the possible reason for the complete degradation of NAP, PHE, and PYR caused by the addition of crude oil is that there are short linear and branched alkanes with simple structure in crude oil [48]. They can not only provide a relatively high-quality carbon source for the P\&A bacterial consortium, which greatly increased the bioaccumulation in the system in a short time, but also stimulate the P\&A bacterial consortium to produce corresponding degradation enzymes to accelerate the degradation rates of NAP, PHE, and PYR. After the easily degradable short chain alkanes and straight chain alkanes were consumed, a large number of bacteria began to degrad the NAP, PHE, and PYR; therefore, its degradation rate was greatly increased. 


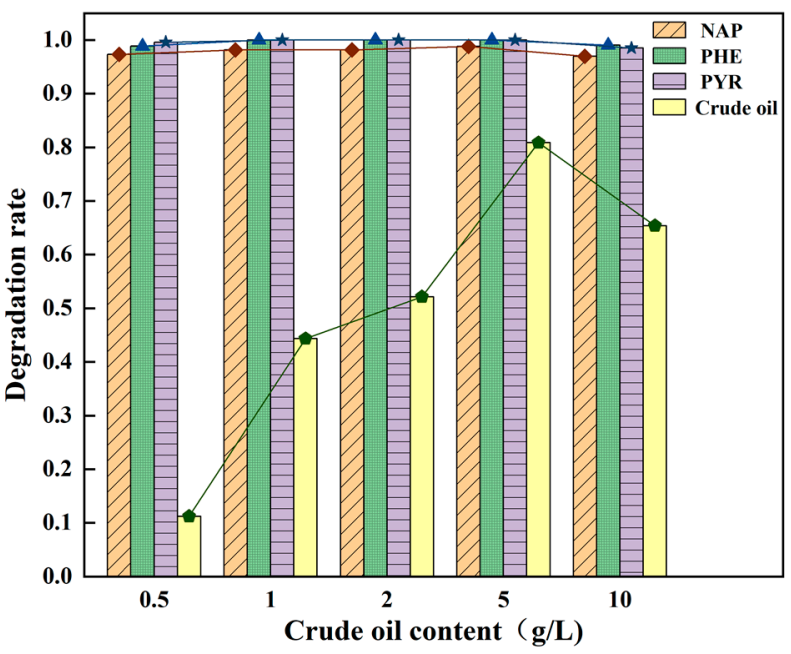

Figure 6. Effect of initial oil content on PAHs degradation efficiency $(\diamond$ : NAP degradation rate; $\Delta$ : PHE degradation rate; $\grave{s}:$ PYR degradation rate; $\triangle$ : Crude oil degradation rate).

The possible reason for the different crude oil degradation rates (Figure 6) is that, under appropriate stimulation, microorganisms can emulsify crude oil by changing the hydrophobicity of cell surface or secreting biosurfactants themselves $[49,50]$. This effect is limited when crude oil content is insufficient, and the crude oil is difficult to disperse in the solute, resulting in its low degradation rate. With the increase of crude oil content (to $5 \mathrm{~g} / \mathrm{L}$ ), this effect is gradually obvious. However, when the crude oil content increases to $10 \mathrm{~g} / \mathrm{L}$, the intermediate products produced by crude oil are toxic to the P\&A bacterial consortium (the results of viable bacteria count showed that the number of viable bacteria was lower than others), which lead to the crude oil degradation rate declining.

\subsubsection{Heavy Metal Ions}

Sensitivity Analysis

Heavy metals are common components in oily sludge. In the process of microbial treatment of oily sludge, many heavy metals become protein-precipitant and cause microbial death. Some of microorganisms exhibit a biphasic response to a number of heavy metals $\left(\mathrm{Cu}^{2+}, \mathrm{Zn}^{2+}\right)$; an appropriate amount of heavy metals contribute to the growth of microorganisms, but they kill microorganisms if excessive [51]. Other metals have toxic effects $\left(\mathrm{Pb}^{2+}\right)$ at a low concentrations. Previous experiments ignored the disadvantage of heavy metals. Therefore, it is necessary to explore the sensitivity and resistance of P\&A bacterial consortium to heavy metal particles. The bacteriostatic circles produced by the P\&A bacterial consortium are shown in Figure 7, and the average diameter of the bacteriostatic circles are shown in Table 4.

Table 4. Average diameter of bacteriostatic circles produced by DSTP.

\begin{tabular}{|c|c|c|c|c|c|c|c|c|c|}
\hline \multirow{3}{*}{$\begin{array}{c}\text { Compound } \\
\text { Concentration } \\
(\mathrm{g} / \mathrm{L})\end{array}$} & \multicolumn{9}{|c|}{ Average Diameter of Bacteriostatic Circles (mm) } \\
\hline & \multicolumn{3}{|c|}{$\mathrm{CuSO}_{4} \cdot 5 \mathrm{H}_{2} \mathrm{O}$} & \multicolumn{3}{|c|}{$\mathrm{ZnSO}_{4} \cdot 7 \mathrm{H}_{2} \mathrm{O}$} & \multicolumn{3}{|c|}{$\mathrm{Pb}\left(\mathrm{NO}_{3}\right)_{2}$} \\
\hline & 1-1 & 1-6 & P\&A & 1-1 & $1-6$ & P\&A & $1-1$ & $1-6$ & P\&A \\
\hline 0.1 & - & - & - & - & - & - & - & - & - \\
\hline 0.5 & - & 7 & 7 & - & - & - & - & - & - \\
\hline 1 & - & 8 & 13 & - & - & - & - & - & - \\
\hline 5 & - & 9 & 16 & - & 10 & 5 & - & - & 7 \\
\hline 10 & 15 & 16 & 22 & 8 & 12 & 10 & 8 & - & 10 \\
\hline 20 & 30 & 30 & 30 & 16 & 14 & 19 & 11 & 8 & 13 \\
\hline
\end{tabular}




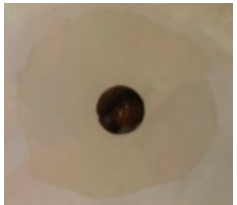

$20 \mathrm{~g} / \mathrm{L}(30 \mathrm{~mm}) \quad 10 \mathrm{~g} / \mathrm{L}(22 \mathrm{~mm})$

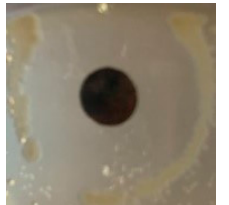

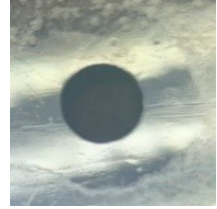

$5 \mathrm{~g} / \mathrm{L}(16 \mathrm{~mm})$

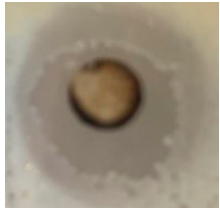

$1 \mathrm{~g} / \mathrm{L}(13 \mathrm{~mm})$

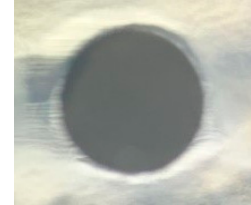

$0.5 \mathrm{~g} / \mathrm{L}(7 \mathrm{~mm})$

(a)

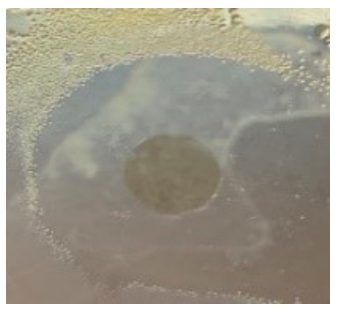

$20 \mathrm{~g} / \mathrm{L}(19 \mathrm{~mm})$

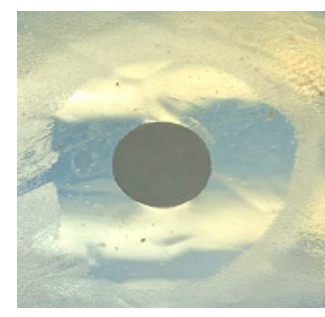

$10 \mathrm{~g} / \mathrm{L}(14 \mathrm{~mm})$

(b)

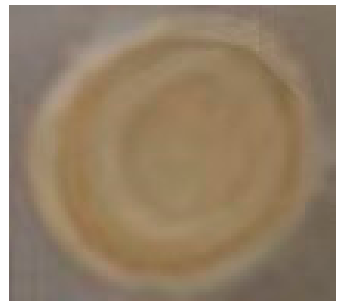

$10 \mathrm{~g} / \mathrm{L}(10 \mathrm{~mm})$

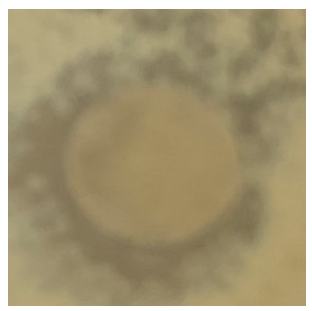

$5 \mathrm{~g} / \mathrm{L}(8 \mathrm{~mm})$

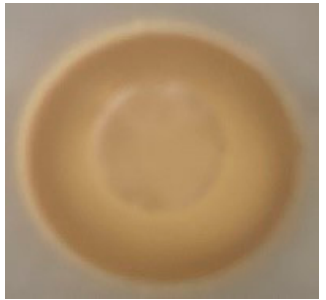

$20 \mathrm{~g} / \mathrm{L}(13 \mathrm{~mm})$

(c)

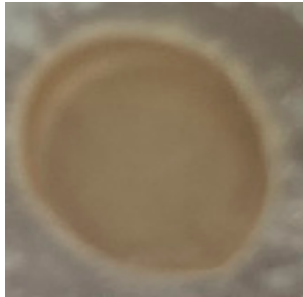

$5 \mathrm{~g} / \mathrm{L}(7 \mathrm{~mm})$

Figure 7. Bacteriostatic circles produced by different DSTP. (a) Bacteriostatic circles produced by $\mathrm{CuSO}_{4} \cdot 5 \mathrm{H}_{2} \mathrm{O}$ DSTP. (b) Bacteriostatic circles produced by $\mathrm{ZnSO}_{4} \cdot 7 \mathrm{H}_{2} \mathrm{O}$ DSTP. (c) Bacteriostatic circles produced by $\mathrm{Pb}\left(\mathrm{NO}_{3}\right)_{2}$ DSTP.

DSTP is lied tightly on the surface of LB solid medium, which was inoculated with different bacterium. The heavy metal ions in the paper diffuse in agar, and the concentration of heavy metal ions decreases logarithmically with the extension of diffusion distance. The bacterium forms a transparent bacteriostatic circle around the paper. The size of bacteriostatic circle can reflect the sensitivity of bacteria to heavy metal ions. Additionally, it has a negative correlation with the MIC, that is, the larger the diameter of bacteriostatic circle, the higher the antibacterial activity [52]. It can be seen from Figure 7 and Table 4 that, with the increase of the concentration of heavy metal ions, the diameters of the bacteriostatic circles are also increased. When the concentrations of compounds are higher than $0.5,5$, and $5 \mathrm{~g} / \mathrm{L}$, respectively (i.e., the concentrations of $\mathrm{Cu}^{2+}, \mathrm{Zn}^{2+}$, and $\mathrm{Pb}^{2+}$ are higher than $2.002,17.388$, and $15.096 \mathrm{mM}$, respectively), the growth of bacterium was inhibited.

\section{Resistance Analysis}

The negative effects of compound concentrations on the growth of P\&A bacterial consortium are shown in Figure 8.

The MIC of P\&A bacterial consortium to different compounds were $0.5 \mathrm{~g} / \mathrm{L}\left(\mathrm{Cu}^{2+}\right.$ $2.002 \mathrm{mM}), 5 \mathrm{~g} / \mathrm{L}\left(\mathrm{Zn}^{2+} 17.388 \mathrm{mM}\right)$, and $3.125 \mathrm{~g} / \mathrm{L}\left(\mathrm{Pb}^{2+} 9.435 \mathrm{mM}\right)$, respectively, which are higher than the reported contents of $\mathrm{Cu}^{2+}, \mathrm{Zn}^{2+}$, and $\mathrm{Pb}^{2+}$ in oil sludge [53]. It indicates that $\mathrm{P} \& A$ bacterial consortium can tolerate high concentrations of $\mathrm{Cu}^{2+}, \mathrm{Zn}^{2+}$, and $\mathrm{Pb}^{2+}$, and grow normally in oily sludge. 


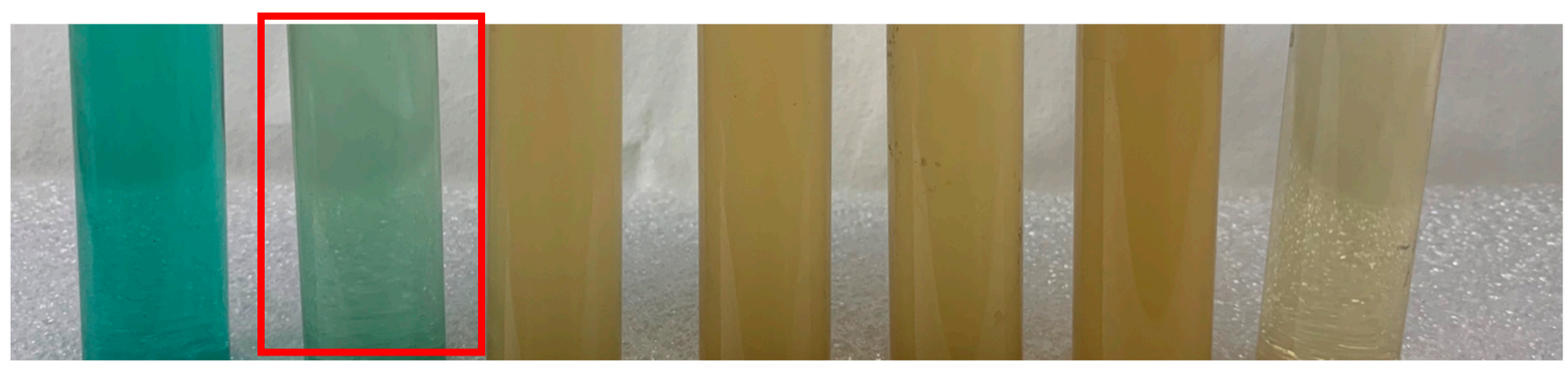

$1.5625 \mathrm{~g} / \mathrm{L} \quad 0.7813 \mathrm{~g} / \mathrm{L} \quad 0.3906 \mathrm{~g} / \mathrm{L} \quad 0.1953 \mathrm{~g} / \mathrm{L} \quad 0.0977 \mathrm{~g} / \mathrm{L} \quad 0 \mathrm{~g} / \mathrm{L} \quad$ bacterial free

(a)

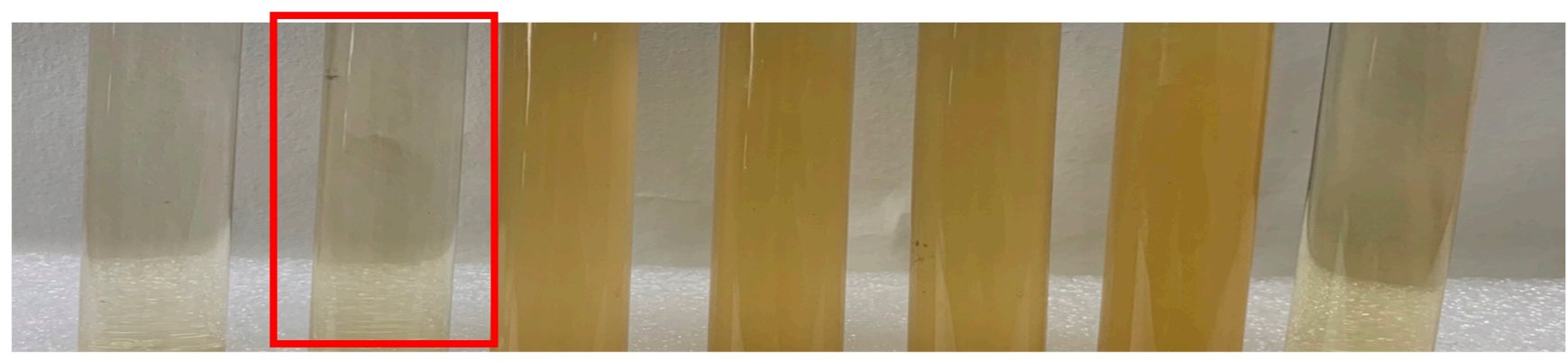

$12.5000 \mathrm{~g} / \mathrm{L} \quad 6.2500 \mathrm{~g} / \mathrm{L} \quad 3.1250 \mathrm{~g} / \mathrm{L} \quad 1.5625 \mathrm{~g} / \mathrm{L} \quad 0.7813 \mathrm{~g} / \mathrm{L} \quad 0 \mathrm{~g} / \mathrm{L} \quad$ bacterial free

(b)

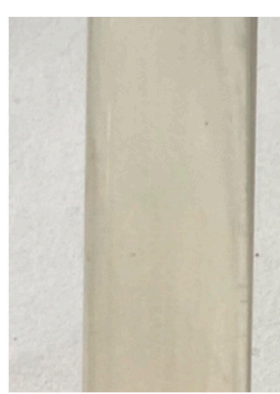

$6.2500 \mathrm{~g} / \mathrm{L}$

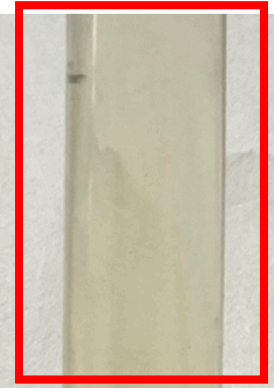

$3.1250 \mathrm{~g} / \mathrm{L}$

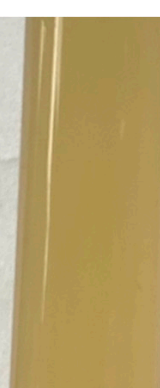

$1.5625 \mathrm{~g} / \mathrm{L}$

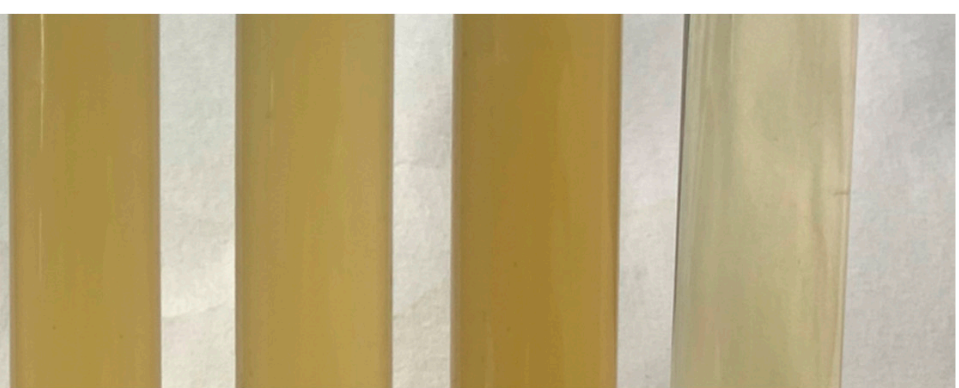

$0.7813 \mathrm{~g} / \mathrm{L}$

$0.3906 \mathrm{~g} / \mathrm{L} \quad 0 \mathrm{~g} / \mathrm{L}$

bacterial free

(c)

Figure 8. Resistance of $\mathrm{P} \& \mathrm{~A}$ bacterial consortium to different concentrations of different compounds. (a) Resistance of $\mathrm{P} \& \mathrm{~A}$ bacterial consortium to different concentrations of $\mathrm{CuSO}_{4} \cdot 5 \mathrm{H}_{2} \mathrm{O}$. (b) Resistance of $\mathrm{P} \& \mathrm{~A}$ bacterial consortium to different concentrations of $\mathrm{ZnSO}_{4} \cdot 7 \mathrm{H}_{2} \mathrm{O}$. (c) Resistance of $\mathrm{P} \& \mathrm{~A}$ bacterial consortium to different concentrations of $\mathrm{Pb}\left(\mathrm{NO}_{3}\right)_{2}$.

\subsubsection{Surfactants}

Many types of surfactants have a high solubilization effect on PAHs [54] and emulsification and dispersion on crude oil [55]. In order to investigate the effect of surfactants on PAHs degradation, four surfactants aqueous solutions (Tween-80, TritonX-100, APG-1214, and Sodium dodecyl sulfate) were added into different media under their critical micelle concentrations (CMC, 100, 50, 500, and $500 \mathrm{mg} / \mathrm{L}$ ).

Due to the addition of surfactant, the degradation rates of NAP, PHE, and PYR in the Tween- 80 group were decreased to $87.85 \%, 52.32 \%$, and $40.95 \%$, and those in the APG- 1214 group were decreased to $86.24 \%, 66.07 \%$, and $61.72 \%$. The degradation rates of crude oil in all groups were increased (Figure 9). This indicates that surfactants preferentially 
increase the solubility of crude oil; thus, the degradation rate of crude oil is increased. As shown in Figures 6 and 9, although the NAP, PHE, and PYR degradation rates in the Triton $\mathrm{X}-100$ group do not decrease significantly, the crude oil degradation rate only increases by $3.85 \%$ (from $80.85 \%$ to $84.70 \%$ ). It can be seen that the non-ionic surfactant (Tween- 80 and APG-1214) had negative effect on the degradation of NAP, PHE, and PYR in the presence of crude oil, and the negative effects of non-ionic surfactant (Triton X-100) and anionic surfactant (SDS) are not obvious. However, their positive effects are also very limited, which means that no additional surfactants are needed.

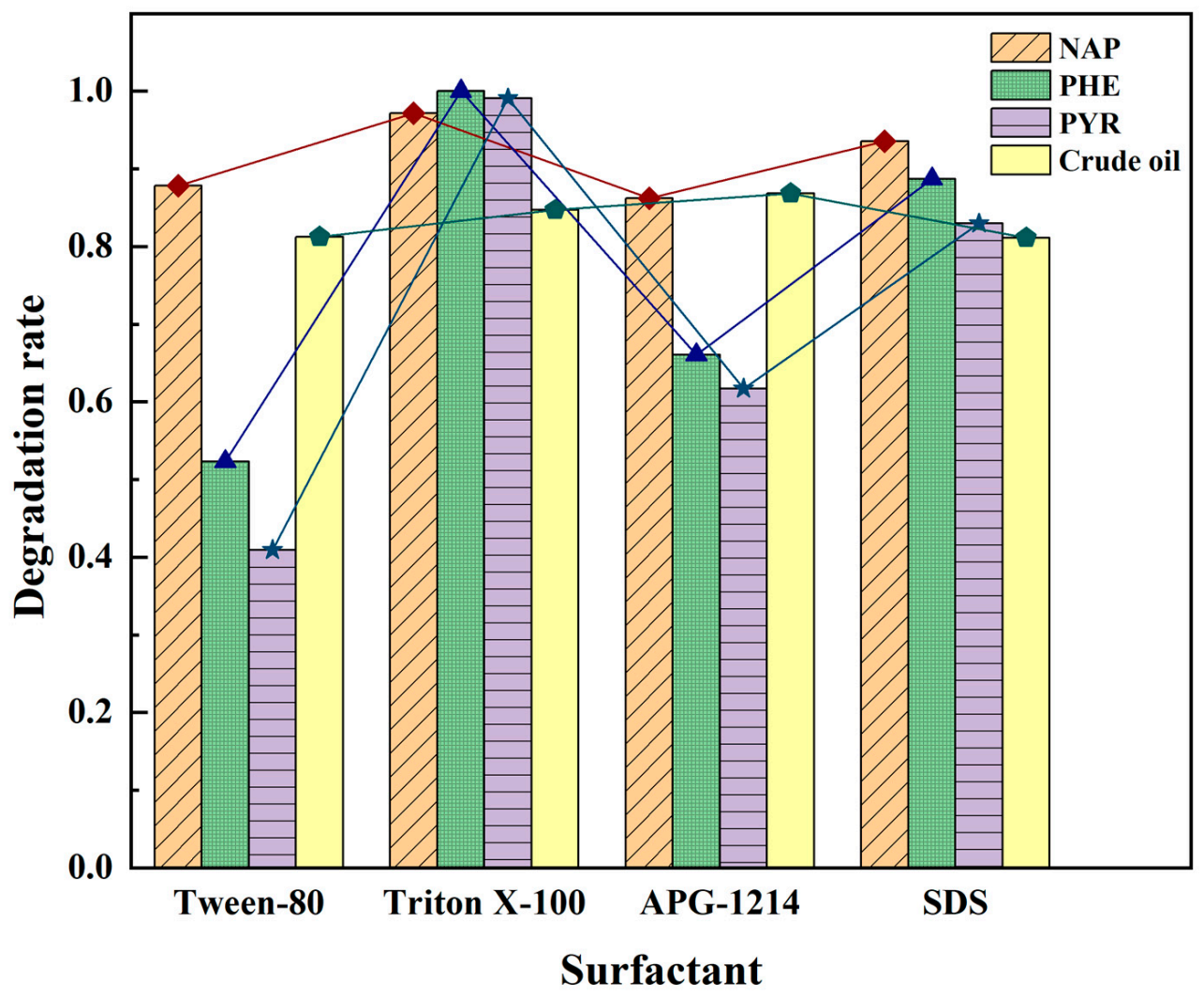

Figure 9. Effects of surfactants on the degradation efficiency of PAHs $(\diamond:$ NAP degradation rate; $\Delta$ : PHE degradation rate; $九$ : PYR degradation rate; $\triangle$ : Crude oil degradation rate).

\subsection{Degradation of PAHs in Oily Sludge by PEA Bacterial Consortium}

The PAHs degradation study in this paper above were conducted under ideal conditions. However, there are many uncontrollable factors in the degradation process of PAHs in actual oily sludge, leading to the differences in degradation effect between them. Therefore, the oily sludge from oil polluted area in Shaanxi Province, China, was used to test the practical application possibility of P\&A bacterial consortium in the test below (Figures 10 and 11).

The P\&A bacterial consortium was used to degrade oily sludge that did not only contain NAP, PHE, and PYR $(0.2090 \mathrm{mg} / \mathrm{g}$ NAP, $3.1116 \mathrm{mg} / \mathrm{g}$ PHE, and $1.00595 \mathrm{mg} / \mathrm{g}$ PYR $)$ but also other types of PAHs compunds. After 8 days, more than $80 \%$ of NAP, PHE, and PYR was degraded in triplicate parallel groups experiments (Figure 10). At the same time, it was found from chromatogram analysis of oily sludge that the P\&A bacterial consortium had the ability to degrade Acenaphthylene, $1 \mathrm{H}$-Phenalene, $4 \mathrm{H}$-Cyclopenta[d,e,f]phenanthrene, Fluoranthene, Triphenylene, 9H-Cyclopenta[a]pyrene, and Benzo[k]fluoranthene in oily sludge (Figure 11). 


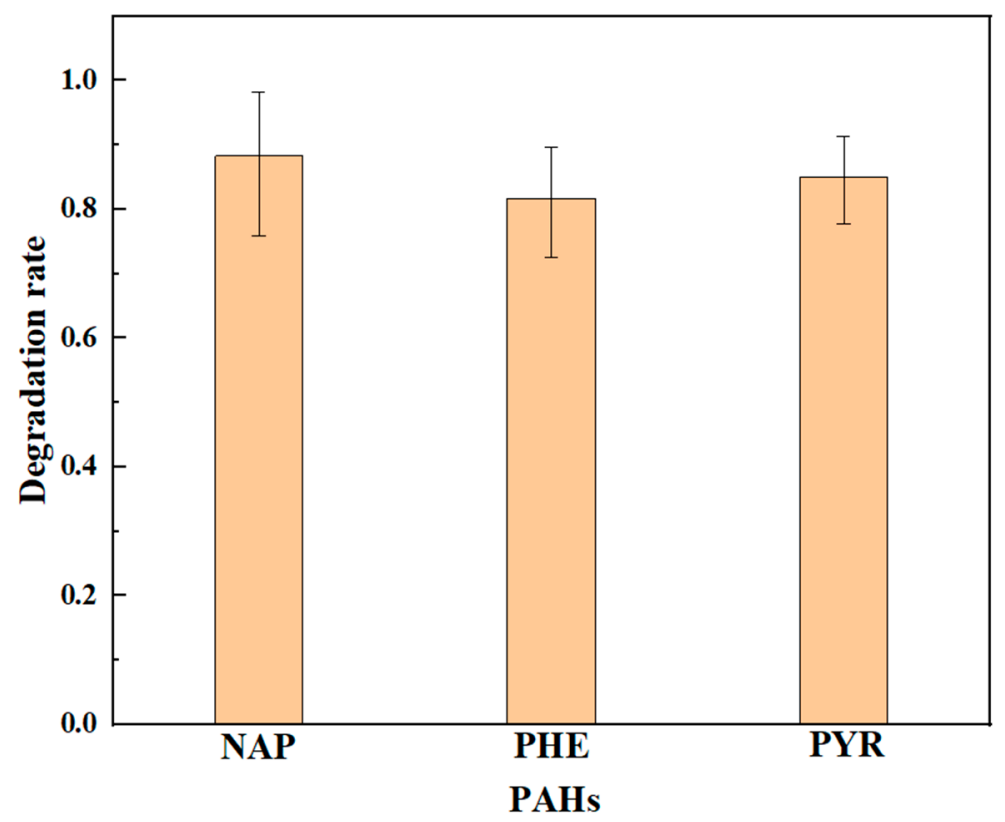

Figure 10. Degradation of PAHs in oily sludge by PA bacterial consortium.

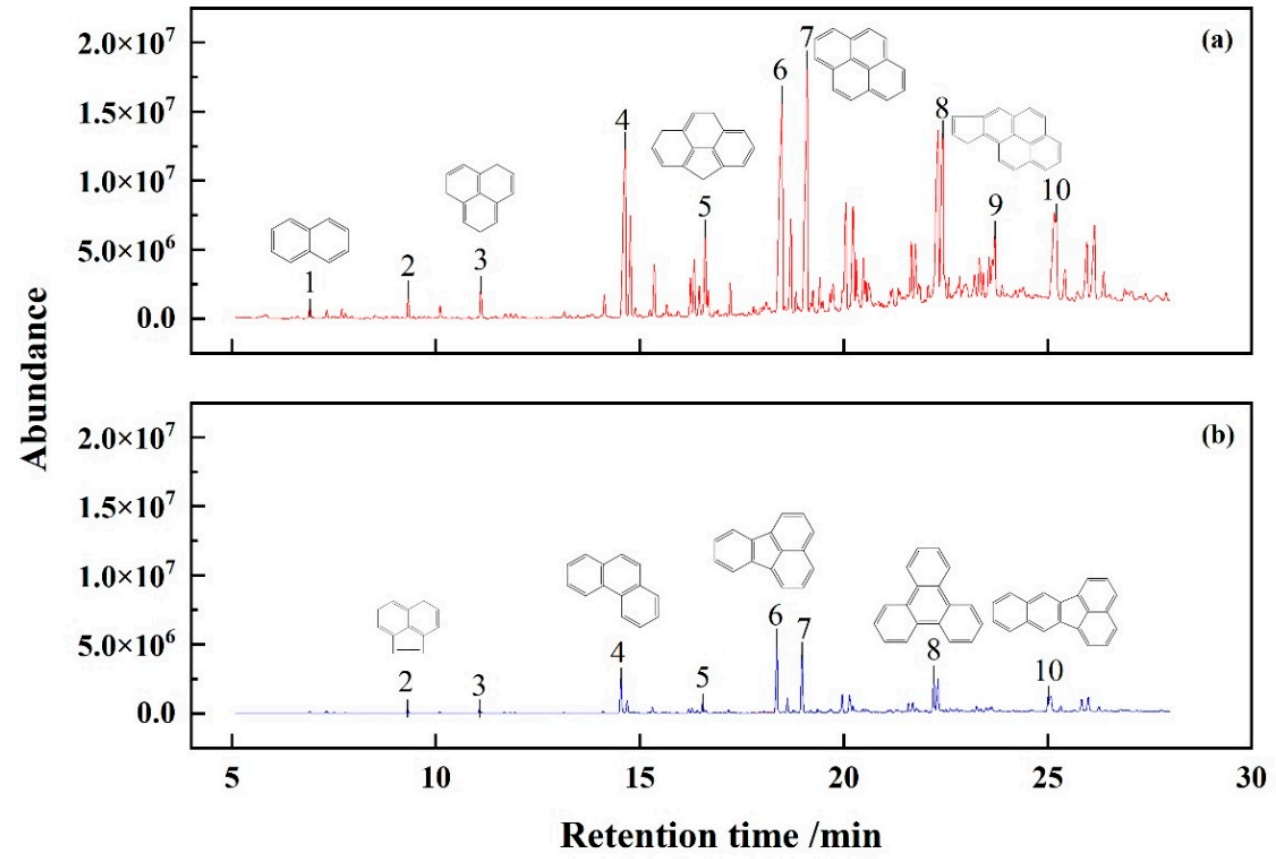

Figure 11. Chromatogram analysis of oily sludge. (a) Chromatographic analysis of oily sludge before degradation; (b) chromatographic analysis of degraded oily sludge; 1 . Naphthalene; 2. Acenaphthylene; 3. 1H-Phenalene; 4. Phenalene; 5. 4H-Cyclopenta[d,e,f]phenanthrene; 6. Fluoranthene; 7. Pyrene; 8. Triphenylene; 9. 9H-Cyclopenta[a]pyrene; 10. Benzo[k]fluoranthene).

\section{Conclusions}

An optimal PAHs degradation bacterial consortia (P. aeruginosa and A. faecalis) and their volume ratio (1:1) were screened out by this study from 10 bacterium in local oily sludge. The PAHs solution degradation efficient of P\&A bacterial consortium under different environmental conditions, bioaugmentations, and exogenous stimulations were studied by UV-vis spectrophotometer and GC-MS. The result shows that, after 8 days degradation under $35^{\circ} \mathrm{C}$, pH 7, with $5 \%$ (volume percent) of the inoculation amount, the degradation 
rates of $2000 \mathrm{mg} / \mathrm{L} \mathrm{NAP,} 20 \mathrm{mg} / \mathrm{L}$ PHE, and $40 \mathrm{mg} / \mathrm{L}$ PYR were higher than 90\%, 80\%, and $70 \%$, respectively. In the report of Sponza et al. and Ventaka et al., the highest biodegradation rates of PHE and PYR were only $74 \%$ and $60 \%$ [56,57], although A. Arun et al. used C. versicolor and F. palustris, which could degraded $93.7 \%$ of PYR, but its degradation term was as long as $28 \mathrm{~d}$ [58]. In contrast, the P\&A bacterial consortium has more advantages in degradation efficiency and degradation term. Additionally, the experimental results also show that the additional crude oil further improved the degradation efficiency of P\&A bacterial consortium. The MIC values of $\mathrm{Cu}^{2+}, \mathrm{Zn}^{2+}$, and $\mathrm{Pb}^{2+}$ to bacterium were 2.002, 17.388 , and $9.435 \mathrm{mM}$, respectively. The addition of surfactants had a negative or limited positive effect on the PAHs degradation rate. Furthermore, the average degradation rates of NAP, PHE, and PYR in oily sludge by P\&A bacterial consortium also reached above $80 \%$. Based on GC-MS test result before and after incubation, PAHs degradation ability of P\&A bacterial consortium is not only limited to NAP, PHE, and PYR, but also includes others such as Acenaphthylene, $1 \mathrm{H}-$ Phenalene, $4 \mathrm{H}$-Cyclopenta[d,e,f]phenanthrene, Fluoranthene, Triphenylene, 9H-Cyclopenta[a]pyrene, and Benzo[k]fluoranthene. However, there are few reports on the degradation of PAHs mixture in oily sludge by bacterial consortium.

The P\&A bacterial consortium has outstanding performance on PAHs degradation activity in oil sludge and high concentration heavy metal ion environment. Based on this advantage, the P\&A bacterial consortium can be prepared into immobilized microorganisms to improve the microbial cell density in unit volume medium and further improve its anti-toxic ability. At the same time, the carrier material can act as a loosening agent. It also can wrap the nutrients by microorganisms to play a stable role in complex environment, which means that the P\&A bacterial consortium has prospects in the application in oily sewage, oily sludge, and soil treatment.

Author Contributions: Formal analysis, C.Q. and F.Q.; investigation, A.M.; resources, T.Y.; data curation, L.Z. and B.Y.; writing-original draft preparation, L.Z. and B.Y.; writing—review and editing, G.C. and F.Q. All authors have read and agreed to the published version of the manuscript.

Funding: The open project of the State Key Laboratory of Petroleum and Petrochemical Pollutant Control and Treatment' Study on the Mechanism of Supercritical Hydrothermal Catalytic Oxidation of Oily Sludge' (subject number PPC2019001); The Open Project of Shaanxi Key Laboratory of Oil and Gas Field Environmental Pollution Control Technology and Reservoir Protection' Study on Ecological Safety Evaluation of Oily Sludge Residue after Treatment'; Major low-carbon project of PetroChina: Research on pyrolysis catalyst and catalytic process conditions of oily sludge (School No. 240113001).

Institutional Review Board Statement: Not applicable.

Informed Consent Statement: Not applicable.

Data Availability Statement: Not applicable.

Acknowledgments: This study was partially supported by the open project of the State Key Laboratory of Petroleum and Petrochemical Pollutant Control and Treatment' Study on the Mechanism of Supercritical Hydrothermal Catalytic Oxidation of Oily Sludge' (subject number PPC2019001) and the Open Project of Shaanxi Key Laboratory of Oil and Gas Field Environmental Pollution Control Technology and Reservoir Protection' Study on Ecological Safety Evaluation of Oily Sludge Residue after Treatment'. We also thank the work of the Modern Analysis and Testing Center of Xi'an Shiyou University.

Conflicts of Interest: The authors declare no conflict of interest.

\section{References}

1. Ghosh, P.; Mukherji, S. Environmental contamination by heterocyclic Polynuclear aromatic hydrocarbons and their microbial degradation. Bioresour. Technol. 2021, 341, 125860. [CrossRef] [PubMed]

2. Rojo-Nieto, E.; Perales-Vargas-Machuca, J.A. Microbial degradation of PAHs: Organisms and environmental compartments. In Microbial Degradation of Xenobiotics; Environmental Science and Engineering; Springer: New York, NY, USA, $2012 ;$ pp. 263-290.

3. Dhar, K.; Subashchandrabose, S.R.; Venkateswarlu, K.; Krishnan, K.; Megharaj, M. Anaerobic Microbial Degradation of Polycyclic Aromatic Hydrocarbons: A Comprehensive Review. Rev. Environ. Contam. Toxicol. 2020, 251, 25-108. [CrossRef] [PubMed] 
4. Achten, C.; Cheng, S.; Straub, K.L.; Hofmann, T. The lack of microbial degradation of polycyclic aromatic hydrocarbons from coal-rich soils. Environ. Pollut. 2011, 159, 623-629. [CrossRef] [PubMed]

5. Achten, C.; Hofmann, T. Native polycyclic aromatic hydrocarbons (PAH) in coals-A hardly recognized source of environmental contamination. Sci. Total Environ. 2009, 407, 2461-2473. [CrossRef]

6. Haritash, A.K.; Kaushik, C.P. Biodegradation aspects of polycyclic aromatic hydrocarbons (PAHs): A review. J. Hazard. Mater. 2009, 169, 1-15. [CrossRef]

7. Gou, Y.; Zhao, Q.; Yang, S.; Qiao, P.; Cheng, Y.; Song, Y.; Sun, Z.; Zhang, T.; Wang, L.; Liu, Z. Enhanced degradation of polycyclic aromatic hydrocarbons in aged subsurface soil using integrated persulfate oxidation and anoxic biodegradation. Chem. Eng. J. 2020, 394, 125040. [CrossRef]

8. Hesham, A.E.-L.; Mawad, A.M.M.; Mostafa, Y.M.; Shoreit, A. Study of enhancement and inhibition phenomena and genes relating to degradation of petroleum polycyclic aromatic hydrocarbons in isolated bacteria. Microbiology 2014, 83, 599-607. [CrossRef]

9. Jasmine, J.; Mukherji, S. Characterization of oily sludge from a refinery and biodegradability assessment using various hydrocarbon degrading strains and reconstituted consortia. J. Environ. Manag. 2015, 149, 118-125. [CrossRef]

10. Thyssen, J.; Kimmerle, G.; Althoff, J.; Mohr, U. Inhalation Studies With Benzo[a]pyrene in Syrian Golden Hamsters. J. Natl. Cancer Inst. 1981, 66, 575-577. [CrossRef]

11. Teixeira, E.C.; Pra, D.; Idalgo, D.; Henriques, J.A.; Wiegand, F. DNA-damage effect of polycyclic aromatic hydrocarbons from urban area, evaluated in lung fibroblast cultures. Environ. Pollut. 2012, 162, 430-438. [CrossRef]

12. Bansal, V.; Kim, K.H. Review of PAH contamination in food products and their health hazards. Environ. Int. 2015, 84, 26-38. [CrossRef] [PubMed]

13. Kim, E.-J.; Oh, J.-E.; Chang, Y.-S. Effects of forest fire on the level and distribution of PCDD/Fs and PAHs in soil. Sci. Total Environ. 2003, 311, 177-189. [CrossRef]

14. Bumpus, J.A.; Aust, S.D. Biodegradation of environmental pollutants by the white rot fungus Phanerochaete chrysosporium: Involvement of the lignin degrading system. Bioessays 2010, 6, 166-170. [CrossRef]

15. Miller, R.L.; Garfinkel, R.; Horton, M.; Camann, D.; Perera, F.P.; Whyatt, R.M.; Kinney, P.L. Polycyclic aromatic hydrocarbons, environmental tobacco smoke, and respiratory symptoms in an inner-city birth cohort. Chest 2004, 126, 1071-1078. [CrossRef]

16. United States Environmental Protection Agency. An Exposure and Risk Assessment for Benzo(a)pyrene and Other Polycyclic Aromatic Hydrocarbons; United States Environmental Protection Agency: Washington, DC, USA, 1982.

17. United States Environmental Protection Agency. Polycyclic Aromatic Hydrocarbons (PAHs); United States Environmental Protection Agency: Washington, DC, USA, 2008.

18. European Comission. Opinion of the SCF on the Risks to Human Health of Polycyclic Aromatic Hydrocarbons in Food; SCF/CS/CNTM/ $\mathrm{PAH} / 29$ Final; European Comission: Brussels, The Netherlands, 2002.

19. Cheng, M.; Zeng, G.; Huang, D.; Lai, C.; Xu, P.; Zhang, C.; Liu, Y. Hydroxyl radicals based advanced oxidation processes (AOPs) for remediation of soils contaminated with organic compounds: A review. Chem. Eng. J. 2016, 284, 582-598. [CrossRef]

20. Wang, J.; Wang, S. Activation of persulfate (PS) and peroxymonosulfate (PMS) and application for the degradation of emerging contaminants. Chem. Eng. J. 2018, 334, 1502-1517. [CrossRef]

21. Kong, F.X.; Sun, G.D.; Liu, Z.P. Degradation of polycyclic aromatic hydrocarbons in soil mesocosms by microbial/plant bioaugmentation: Performance and mechanism. Chemosphere 2018, 198, 83-91. [CrossRef]

22. Shao, B.; Tan, X.; Li, J.L.; He, M.; Tian, L.; Chen, W.J.; Lin, Y. Enhanced treatment of shale gas fracturing waste fluid through plant-microbial synergism. Environ. Sci. Pollut. Res. Int. 2021, 28, 29919-29930. [CrossRef]

23. Robinson, S.L.; Novak, J.T.; Widdowson, M.A.; Crosswell, S.B.; Fetterolf, G.J. Field and Laboratory Evaluation of the Impact of Tall Fescue on Polyaromatic Hydrocarbon Degradation in an Aged Creosote-Contaminated Surface Soil. J. Environ. Eng. 2003, 129, 232-240. [CrossRef]

24. Kamath, R.; Schnoor, A.J.L.; Alvarez, P.J.J. Effect of Root-Derived Substrates on the Expression ofnah-luxGenes in Pseudomonas fluorescens HK44: Implications for PAH Biodegradation in the Rhizosphere. Environ. Sci. Technol. 2004, 38, 1740-1745. [CrossRef]

25. Muratova, A.; Hübner, T.; Tischer, S.; Turkovskaya, O.; Möder, M.; Kuschk, P. Plant-Rhizosphere-Microflora Association during Phytoremediation of PAH-Contaminated Soil. Int. J. Phytoremediat. 2003, 5, 137-151. [CrossRef] [PubMed]

26. Dominguez, J.J.A.; Inoue, C.; Chien, M.F. Hydroponic approach to assess rhizodegradation by sudangrass (Sorghum $\times$ drummondii) reveals $\mathrm{pH}$ - and plant age-dependent variability in bacterial degradation of polycyclic aromatic hydrocarbons (PAHs). J. Hazard. Mater. 2020, 387, 121695. [CrossRef] [PubMed]

27. Fortin Faubert, M.; Desjardins, D.; Hijri, M.; Labrecque, M. Willows Used for Phytoremediation Increased Organic Contaminant Concentrations in Soil Surface. Appl. Sci. 2021, 11, 2979. [CrossRef]

28. Sakshi; Haritash, A.K. A comprehensive review of metabolic and genomic aspects of PAH-degradation. Arch. Microbiol. 2020, 202, 2033-2058. [CrossRef] [PubMed]

29. Taha, M.; Shahsavari, E.; Aburto-Medina, A.; Foda, M.F.; Clarke, B.; Roddick, F.; Ball, A.S. Bioremediation of biosolids with Phanerochaete chrysosporium culture filtrates enhances the degradation of polycyclic aromatic hydrocarbons (PAHs). Appl. Soil Ecol. 2018, 124, 163-170. [CrossRef]

30. Zhang, L.; Qiu, X.; Huang, L.; Xu, J.; Wang, W.; Li, Z.; Xu, P.; Tang, H. Microbial degradation of multiple PAHs by a microbial consortium and its application on contaminated wastewater. J. Hazard. Mater. 2021, 419, 126524. [CrossRef] [PubMed] 
31. Juhasz, A.; Stanley, G.; Britz, M. Microbial degradation and detoxification of high molecular weight polycyclic aromatic hydrocarbons by Stenotrophomonas maltophilia strain VUN 10,003. Lett. Appl. Microbiol. 2010, 30, 396-401. [CrossRef]

32. Trzesicka-Mlynarz, D.; Ward, O.P. Degradation of polycyclic aromatic hydrocarbons (PAHs) by a mixed culture and its component pure cultures, obtained from PAHmcontaminated soil. Can. J. Microbiol. 1995, 41, 470. [CrossRef]

33. Tadros, M.G.; Hughes, J.B. Degradation of Polycyclic Aromatic Hydrocarbons (PAHs) by Indigenous Mixed and Pure Cultures Isolated from Coastal Sediments. Appl. Biochem. Biotechnol. 1997, 63, 865-870. [CrossRef]

34. Muangchinda, C.; Rungsihiranrut, A.; Prombutara, P.; Soonglerdsongpha, S.; Pinyakong, O. 16S metagenomic analysis reveals adaptability of a mixed-PAH-degrading consortium isolated from crude oil-contaminated seawater to changing environmental conditions. J. Hazard. Mater. 2018, 357, 119-127. [CrossRef]

35. Nana, X. Bioadsorption, Uptake and Biodegradation of Polycyclic Aromatic Hydrocarbons by PH Microbial Consortium; Ocean University of China: Qingdao, China, 2014.

36. Zhao, X.; Wang, Y.; Ye, Z.; Borthwick, A.G.L.; Ni, J. Oil field wastewater treatment in Biological Aerated Filter by immobilized microorganisms. Process Biochem. 2006, 41, 1475-1483. [CrossRef]

37. Agrawal, N.; Verma, P.; Shahi, S.K. Degradation of polycyclic aromatic hydrocarbons (phenanthrene and pyrene) by the ligninolytic fungi Ganoderma lucidum isolated from the hardwood stump. Bioresour. Bioprocess. 2018, 5, 11. [CrossRef]

38. Nanca, C.L.; Neri, K.D.; Ngo, A.C.R.; Bennett, R.M.; Dedeles, G.R. Degradation of polycyclic aromatic hydrocarbons by moderately halophilic bacteria from luzon salt beds degradation of pahs by moderately halophilic bacteria. J. Health Pollut. 2019, 8, 180915. [CrossRef]

39. Patel, A.B.; Mahala, K.; Jain, K.; Madamwar, D. Development of mixed bacterial cultures DAK11 capable for degrading mixture of polycyclic aromatic hydrocarbons (PAHs). Bioresour. Technol. 2018, 253, 288-296. [CrossRef]

40. Barone, R.; Nastro, R.A.; Gambino, E.; Toscanesi, M.; Picciall, G.; Napoli, L.D.; Trifuoggi, M.; Piccialli, V.; Guida, M. Pseudomonas anguilliseptica Strain-A1 Degradation of Polycyclic Aromatic Hydrocarbons in Soil Microcosms: Focus on Detoxification Activity and Free Water-Soluble Protein Extracts Kinetics and Efficiency. J. Bioremediat. Biodegrad. 2017, 8, 1-7. [CrossRef]

41. Smith, K.E.; Schwab, A.P.; Banks, M.K. Dissipation of PAHs in saturated, dredged sediments: A field trial. Chemosphere 2008, 72, 1614-1619. [CrossRef]

42. Dezhong, S. Bioremediation of Polluted Environment; Chemical Industry Press: Beijing, China, 2002.

43. Viamajala, S.; Peyton, B.M.; Richards, L.A.; Petersen, J.N. Solubilization, solution equilibria, and biodegradation of PAH's under thermophilic conditions. Chemosphere 2007, 66, 1094-1106. [CrossRef]

44. Hirahara, Y.; Ueno, H.; Nakamuro, K. Aqueous photodegradation of fenthion by ultraviolet B irradiation: Contribution of singlet oxygen in photodegradation and photochemical hydrolysis. Water Res. 2003, 37, 468-476. [CrossRef]

45. Qunying, Z.; Shifen, W. Microbiology of Environmental Engineering; Springer: New York, NY, USA, 2015 ; pp. $155-156$.

46. Hu, G.; Li, J.; Zeng, G. Recent development in the treatment of oily sludge from petroleum industry: A review. J. Hazard. Mater. 2013, 261, 470-490. [CrossRef]

47. Al-Mutairi, N.; Bufarsan, A.; Al-Rukaibi, F. Ecorisk evaluation and treatability potential of soils contaminated with petroleum hydrocarbon-based fuels. Chemosphere 2008, 74, 142-148. [CrossRef]

48. Gurav, R.; Lyu, H.; Ma, J.; Tang, J.; Liu, Q.; Zhang, H. Degradation of n-alkanes and PAHs from the heavy crude oil using salt-tolerant bacterial consortia and analysis of their catabolic genes. Environ. Sci. Pollut. Res. Int. 2017, 24, 11392-11403 [CrossRef] [PubMed]

49. Hong, L. Construction of Salt-Tolerant Petroleum-Degrading Microbiol Consortium and Degradation Performance; Xi'an Shiyou University: Xi'an, China, 2020.

50. Bordoloi, N.K.; Konwar, B.K. Microbial surfactant-enhanced mineral oil recovery under laboratory conditions. Colloids Surf. B Biointerfaces 2008, 63, 73-82. [CrossRef] [PubMed]

51. Sadler, W.R.; Trudinger, P.A. The inhibition of microorganisms by heavy metals. Miner. Depos. 1967, 2, 158-168. [CrossRef]

52. Bauer, M.A.W.; Kirby, M.W.M.M.; Sherris, M.J.C.; Turck, M.M. Antibiotic susceptibility testing by a standardized single disk method. Tech. Bull. Regist. Med. Technol. 1966, 36, 49-52. [CrossRef] [PubMed]

53. Chengtun, Q.; Jinling, L.; Shidong, Z. Treatment Technology of Oily Sludge in Oil and Gas Field; Material Reports: Beijing, China, 2017; pp. 3-4.

54. Fernando Bautista, L.; Sanz, R.; Carmen Molina, M.; González, N.; Sánchez, D. Effect of different non-ionic surfactants on the biodegradation of PAHs by diverse aerobic bacteria. Int. Biodeterior. Biodegrad. 2009, 63, 913-922. [CrossRef]

55. Ramirez, D.; Shaw, L.J.; Collins, C.D. Oil sludge washing with surfactants and co-solvents: Oil recovery from different types of oil sludges. Environ. Sci. Pollut. Res. Int. 2021, 28, 5867-5879. [CrossRef]

56. Sponza, D.T.; Gok, O. Effect of rhamnolipid on the aerobic removal of polyaromatic hydrocarbons (PAHs) and COD components from petrochemical wastewater. Bioresour. Technol. 2010, 101, 914-924. [CrossRef]

57. Venkata Mohan, S.; Prasanna, D.; Purushotham Reddy, B.; Sarma, P.N. Ex situ bioremediation of pyrene contaminated soil in bio-slurry phase reactor operated in periodic discontinuous batch mode: Influence of bioaugmentation. Int. Biodeterior. Biodegrad. 2008, 62, 162-169. [CrossRef]

58. Arun, A.; Raja, P.P.; Arthi, R.; Ananthi, M.; Kumar, K.S.; Eyini, M. Polycyclic aromatic hydrocarbons (PAHs) biodegradation by basidiomycetes fungi, Pseudomonas isolate, and their cocultures: Comparative in vivo and in silico approach. Appl. Biochem. Biotechnol. 2008, 151, 132-142. [CrossRef] 